\title{
Třikrát ve znamení poezie tří národů
}

\author{
Ivo Pospíšil (Brno)
}

Leonid G. Frizman: „Neokončennoje značit nedoskazannoje... “ Kniha o Naume Koržavine. Kijev: Izdatel'skij dom Dmitrija Burago, 2018. 142 s. ISBN 978-617-7349-83-8.

Leonid G. Frizman: Ivan Franko: vzgljad na literaturu. Kijev: Izdatel'skij dom Dmitrija Burago, 2017. 606 s. ISBN 978-966-489-414-9.

Poetika poézie a jej prekladu. Ed. Andrea Bokníková. Bratislava: Univerzita Komenského v Bratislavě, Filozofická fakulta, Katedra slovenskej literatúry a literárnej vedy, 2018. 455 s. ISBN 978-80-223-4638-2.

Všechny tři přítomné publikace se věnují víceméně poezii: poslední uvedená se týká poetiky poezie, tedy nejen versologie, ale všech tvarových komponentů, další dvě analyzují básnickou tvorbu i z hlediska společenské rezonance a zasahují do klasické kreativity i do moderního vývoje, i když také spíše tradicionalistického. Někde se jedná o výslovně umělecké vrstvy poezie, jinde zase o jejich prolnutí ideologickou tendencí a reflexí, jež poznamenaly život autora. Jsou zde představeni básníci a básníŕky, básnická díla a jejich literárněkritické a literárněhistorické a teoretické analýzy, pokaždé trochu jinak, v jiných žánrových strukturách a v jiném metodologickém ustrojení.

Leonid Frizman (1935-2018) je autorem a spoluautorem 45 knih a stovek vědeckých studií. Narodil se a studoval v Charkově. Jeho kniha o ruské elegii (1973) vyšla v Moskvě. ${ }^{1}$ Zabýval se mj. J. A. Boratynským/Baratynským, děkabristy, A. Delvigem, jako Žida ho zaujaly židovské motivy v ruské literatuře: byl to především rusista, což dokládají témata jeho knih a statí, ale napsal také knihu o Ivanu Frankovi a jeho pohledech na literaturu, která ukazuje, jak široké znalosti světové literatury Ivan Franko měl. Zabýval se také A. Tvardovským, A. Galičem, psal portréty blízkých literárních vědcủ. ${ }^{2} \mathrm{O}$ jeho

1 FRIZMAN, Leonid: Žizń liričeskogo žanra: Russkaja elegija ot Sumarokova do Nekrasova. Moskva: Nauka, 1973.

2 Z jeho díla uvádíme zde jen některá: FRIZMAN, Leonid: Tvorčeskij put' Baratynskogo. Moskva: Nauka, 1966; Týž: knize portrétů literárních vědců jsem psal v jiné recenzi, ${ }^{3}$ stejně jako ve zvláštní studii. ${ }^{4}$ Frizmanovy generační paměti reflektují relativně přesně svět, jenž je už minulostí, ačkoliv ne zcela, jako se nikdy všechno z minulosti neztrácí. Je to minuciózní analýza tehdejšího literárního života v SSSR, deptaného cenzurou a autocenzurou, ale také ostrými dobovými spory, osobními půtkami, to, co k nám zavál sovětský vliv od padesátých let 20. století a co nám do jisté míry zůstalo i v sedmdesátých a osmdesátých letech: měl jsem možnost tuto atmosféru, jistě transponovanou do našeho prostředí, zažít na vlastní kůži, včetně nositelů těchto „zvyklosti““, kteří po různých převratech stanuli opět na výši doby.

L. Frizman patřil k mladší generaci sovětských literárních vědců, navíc k ukrajinsko-ruským,

Poezija dekabristov. Moskva: Znanije, 1974; Týž:: 1812 god v russkoj poezii. Moskva: Znanije, 1987; Týž: Dekabristy $i$ russkaja literatura. Moskva: Chudožestvennaja literatura, 1988; Týž: «S čem rifmujetsja slovo istina...»: O poezii A. Galiča. Sankt-Peterburg: Oreol, 1992; Týž: Takaja sudba: Jevrejskaja tema v russkoj literature. Charkov: Folio, 2015; Týž: V krugach literaturovedov. Memuarnyje očerki. Moskva - Sankt-Peterburg: Nestor-Istorija, 2017; Týž: Ivan Franko: vzgljad na literaturu. Kijev: Izdatel'skij dom Dmitrija Burago, 2017.

3 POSPÍŠIL, Ivo: Ztracený svět, drásavá nostalgie (FRIZMAN, Leonid: $V$ krugach literaturovedov. Memuarnyje očrki. Moskva - Sankt-Peterburg: Nestor-Istorija. 2017). Novaja rusistika 12, 2019, č. 2, s. 68-73.

4 POSPÍŠIL, Ivo: Generace v literárni vědě, jejich sláva a traumata. In: Mladá slavistika, IV. Výzkum slovanského areálu: generační proměny. Eds. Zbyněk Michálek - Josef Šaur. Masarykova univerzita, Brno 2019, s. 7-25. 
i když v svých knihách dával přednost ruštině, ale slavná je jeho kniha o Ivanu Frankovi, ale píše hlavně o starších, kteří prošli desítkami let tvrdého stalinismu, ale také chruščovovskou oblevou, spojoval je v mládí také zážitek Velké vlastenecké války. Mohli bychom tedy jeho podobizny literárních vědců nazvat personálními dějinami ruské sovětské literární vědy padesátých a šedesátých let 20. století, nebot všichni jmenovaní se zabývali takřka výlučně ruskou literaturou, v podstatě klasickou, 18. a především 19. stoletím. To byl ostatně i odborný zájem autorův.

Naum Koržavin (vl. jm. Naum Mojsejevič Mandel', 1925-2018) byl pozoruhodnou postavou sovětské poezie a dramatu, esejistiky a literární kritiky. Patřil ke generaci, která se formovala v posledních desetiletích, zejména pod vlivem politiky „tání“, tedy celkového uvolňování cenzury od poloviny padesátých let 20. století po XX. sjezdu KSSS. Koržavin ve svých vzpomínkách upozorňuje na to, že na počátku byl sice odpůrcem stalinismu ve všech jeho projevech, ale nikoli tzv. komunismu, jehož byl naopak vyznavačem, ale v jiné podobě. To se potom modifikovalo až v jeho odmítnutí a nakonec i zdravou nedůvěru $\mathrm{k}$ aktivistům glasnosti a perestrojky, již vyjádřil, když navštívil ke konci osmdesátých let minulého století starou vlast a četl zde - pokud mu to nemocný zrak dovolil - svou poezii. Se sovětským režimem se po nesčetných konfliktech rozešel na počátku sedmdesátých let a požádal o vystěhování. Usadil se v Severní Karolině v Chapel Hill, padesátitisícovém městě, na jehož univerzitě pronesl před více než pětapadesáti lety svưj slavný referát o krizi literární komparatistiky vídeňský rodák a český a americký literární vědec světového jména René Wellek (1903-1995). Nakonec Koržavin zemřel tam, kam ho vzala rodina, totiž v severokarolinském Durhamu, kde na Duke University získal profesuru jeho zet. Do Ruska se však přece jen vrátil, byt' jen v podobě urny s jeho popelem, která byla pohřbena v listopadu 2018 na proslulém Vagaňkovském hřbitově v Moskvě.

Frizman se na svého židovského sovětského spolubojovníka dívá z různých stran a podob- ně pohlíží na jeho dílo. Především je to už jeho vlastně poslední kniha, psal ji jako svoji labutí píseň. A je zřejmé proč. S Koržavinem ho spojuje rozkročení mezi Ruskem a Ukrajinou a také vřelý vztah $\mathrm{k}$ jiným národům jejich širší vlasti, jenž se projevoval v osobních stycích a překladech. Frizman však navíc dobře postihl, že je zde ještě něco, co ho s Koržavinem spojuje, a to je konzervativní pohled na svět, rezervovaný postoj k moderně a avantgardě $\mathrm{s}$ jejich exhibicionistickému experimentátorství, skepse a kritický postoj ke všemu, co je obklopovalo. To prokazoval nejen v SSSR, ale také v USA a v redakci emigrantského časopisu vydávaného v Paříži Kontinent, kam ho pozval slavný sovětský a poté ostře pravicový a náboženský spisovatel a šéfredaktor Vladimir Maximov (vl. jm. Lev Alexejevič Samsonov, 1930-1995). Když zůstaneme u Koržavinovy poezie, je to umění sukovité, nelíbivé, hořce vydřené a ideově kostrbaté, stejně jako Maximovova próza a stejně jako poezie jeho židovského současníka Borise Sluckého, s nímž sdílel nejen generační pocit (Sluckij byl však o něco starší, 1918-1986), ale také rodnou Ukrajinu a silné internacionální cítění. Raný Koržavin, jak na to Frizman upozorňuje, tíhl k lítosti z jakési insuficience, nemožnosti plné lidské realizace: „Можем строчки нанизывать/ Посложнее, попроще, / Но никто нас не вызовет/ на Сенатскую площадь [... VMы не будем увенчаны.../И в кибитках, снегами,/Настоящие женшины/ Не поедут за нами..." Jeho poezie је osobní, vyhraněná, jdoucí proti proudu, nejen proti politickému mainstreamu, ale i proti poetice moderní poezie: je publicistická, drsná, rudimentární, reaguje na aktuální události (procesy s tzv. lékaři-vrahy na konci Stalinova života), chce vyjádřit individualitu navzdory všemu. Nutno si uvědomit, že právě zprostředkování takové zauzlované poezie by bylo v českém prostř̌edí významným kulturním činem, jinak bude náš pohled na ruskou poezii a na ruskou literaturu jako celek deformovaný a jednostranný. Stejně jako je Koržavin konzervativec držící se ruské tradice překonávání umění, vystoupení $\mathrm{z}$ umění směrem $\mathrm{k}$ společenskému sebevyjádření, současně patos neukončenosti naznačený 
v titulu, nebot' umění nikde a nikdy nekončí, je jím i Frizman: jako by v jejich slovech ožívala moudrost starého národa, který se dívá na každodenní pinožení z hlubin tisíciletí.

To nicméně neznamená, že Frizman neumí cítit i jiné bušení srdce, zejména u Slovanů, k nimž ruští a ukrajinští Židé, nehledě na všechna utrpení, tíhli: dokázali rozlišovat mezi antisemitismem vládnoucích kruhů a realizátorů jejich politiky skrytě řízených pogromů, a živelným pocitem ruského a ukrajinského lidu, jenž se projevoval sice někdy hrubě, ale upřímně a přirozeně. Klasik ukrajinské literatury Ivan Franko (1856-1916), člověk pohybující se mezi několika jazyky a literaturami, drohobyčský gymnazista, lvovský univerzitní student a vídeňský „doktorand“: ve Vídni psal disertaci, zúčastnil se kulturního života a psal německé texty, které nedávno vyšly (Vídeňská univerzita roku 2013 odmítla demontovat pamětní desku Ivana Franka obviňovaného $\mathrm{z}$ antisemitismu). Habent sua fata homines... Frizman rozebírá Frankovy pohledy na světovou literaturu. Na prvním místě stojí ovšem ukrajinští umělci, i když nepsali ukrajinsky, jako např́íklad H. Skovoroda, dílem i zakladatel novodobé ukrajinské literatury Ivan Kotlarevskyj nebo Kvitka Osnovjanenko. Jádrem je ovšem jeho pohled na Tarase Ševčenka.

Socialisticky orientovaný Franko vyhledával v ruském prostředí zejména raznočince (jako syn relativně zámožného sedláka a kováře z Haliče) a lidi ideově vyhraněné (Gogol, Saltykov-Ščedrin) a velké autory, jako byli Puškin a Lev Tolstoj; posledně jmenovaného zvláště ve svém realistickém období. Kriticky se díval na své současníky, např. Jurije Fedkovyče nebo Marka Vovčka či Lesju Ukrajinku, kteří začali pozvolna vytvářet předpolí ukrajinské rané moderny. Ze světových autorů měl rád titány typu Danta, Shakespeara, Goetha nebo Byrona, Vzpomeňme v této souvislosti na první vědecké pokusy jeho přítele T. G. Masaryka (1850-1937), jenž také snil o tom, že bude estetikem a literárním kritikem a historikem, který bude psát o titánech tohoto typu. Tíhnutí k velkým osobnostem ostatně Franka provázelo celý život: jeho kontakty s polskou pozitivistkou/realistkou Elizou
Orzeszkowou, zakladatelem sionismu Theodorem Herzlem, vlastně Binjaminem Ze'evem Herzlem, polským dekadentem Stanisławem Przybyszewským nebo spolutvưrcem Vídeňské moderny (die Wiener Moderne) Arthurem Schnitzlerem jsou ostatně dobře známy. A nakonec polská literatura, zejména Adam Mickiewicz a Jan Kasprowicz, trochu také Hassliebe... Složitostí rusko-ukrajinsko-polsko-německo-židovských vztahů si byl Frizman jako člověk stojící mimo přímou haličskou zkušenost silně vědom: literatura má tyto umělé i přirozené bariéry překonávat, vytvářet kulturní mosty - to ostatně všichni tito spisovatelé, které pozorně četl, sami věděli. Franko ve Frizmanově podání vypadává z rámce úzkého artistního vidění; je to nejen básník, prozaik, esejista a publicista, ale pronikavě myslící analytik literatury, literární kritik a snad i historik a teoretik alespoň v zárodečné podobě, jenž literaturu viděl především v národně společenském rámci, i když nejenom.

Znalkyně poezie, zejména slovenské, editorka antologií a tvưrkyně zajímavých studií sestavila a redigovala také festschrift klíčového slovenského básníka a překladatele, literárního vědce a versologa Jána Zambora (nar. 1947): chvilku trvalo, než vyšel, což bylo do značné míry dáno jistě i jeho rozsáhlostí. Důležitý je již název, který se týká morfologie poezie jako takové a také jejího překládání, samozřejmě především tvorby oslavence, ale i otázek versologie a tematiky, strofiky a kompozice poezie. Zamborovi, rodákovi z východního Slovenska, možno jen závidět. Jeho práce si váží jak jeho Filozofická fakulta a Univerzita Komenského, tak slovenští spisovatelé, překladatelé, pracovníci SAV, přičemž jde často o stejné osoby, čtenáři - a dávají to najevo - ne každý má takové štěstí, že jeho dílo vyvolává tak jednoznačně kladné reakce. Pozoruhodný je nejen Zamborův vlastní úvod, ale také vystoupení děkana Jaroslava Šušola, komentář editorky Bokníkové, laudatia různého druhu, která postupně přednášeli mimo jiné Ján Buzássy a Lubomín Feldek, ale také studie a analýzy, jejichž autory jsou Ladislav Šimon, jenž komplexně pojednal o „fenoménu Zambor“ a jeho různorodosti a současně celistvosti, Anton Eliáš, který psal o ruské 
poezii 19. století v překladech oslavence, Mária Kusá, jež si vzala na starost $\mathrm{v}$ jeho překladech zase ruskou poezii 20. století; Paulína Šišmišová se zabývá Zamborovými překlady ze španělsky psané poezie. Nelze však takto sumárně a juxtapozičně postupovat dále; vybíráme tedy jen ty příspěvky, které podle našeho názoru přinášejí něco podstatného, nového nebo koncepčně nosného. $\mathrm{K}$ těmto textům patří mimo jiné studie Anny Valcerové (Viacprúdová poézia), Jána Gavury (Básnik v básni - zviditelnenie tvorcu), Evy Maliti Fraňové (ruské překlady poezie Miroslava Válka a Jána Zambora). Dále tu máme práce, jež se zabývají poezií jako takovou už i mimo okruh tvorby Jána Zambora: takové jsou studie Johna Minahane, Miloslava Vojtecha, z české strany autora této recenze, jenž pojednal o poezii Ladislava Soldána, editorky Andrey Bokníkové (poezie Ludmily Groeblovej), Petra Tollaroviče, Márie Stankové,
Martina Dzúra, Jany Juhásové. Podstatná je také druhá část svazku nazvaná Malý slovnik poetiky koncentrující texty, studie a analýzy Lubomíra Feldeka, Mikuláše Kováče, Ludvíka Kundery, Jána Šimonoviče, Rudolfa Slobody, Jána Švantnera aj. Třetí část tvoří moudrý rozhovor Dušana Teplana s oslavencem, který Zambor uzavírá takto: „Výzvou je pre mña zurchovaný básnický výkon s významnými ludskými obsahmi. V reflexiách poézie slovenských a inonárodných básnikov, ktoré majú ambiciu byt' hĺbkové, som chcel ukázat', s kým máme tú čest.' Zurchovaná báseñ je mojím ideálom pri vlastnom pisani poézie a usilujem sa jej zurchovane zmocnit' aj ako prekladatel'. Moje pokusy pokračujü“ (s. 424). Svazek neulpívá pouze na oslavném tónu, k čemuž by charakter svazku lehce sváděl, není formální, spíše naopak: je nasycen novými obsahy a je opatřen všemi náležitostmi objevného vědeckého spisu, zejména versologického.

prof. PhDr. Ivo Pospíšil, DrSc.

Ústav slavistiky

Filozofická fakulta, Masarykova univerzita

Arna Nováka 1, 60200 Brno, Česká republika

ivo.pospisil@phil.muni.cz 